\title{
Tővégi magánhangzós helynevek a Pécsváradi alapítólevélben*
}

1. A Pécsváradi oklevelet (1015), illetve II. Géza átíró oklevelét (1158) a 13. század első felében, 1220 környékén jegyezhették le (DHA. 1: 67-68). ${ }^{1}$ Az alapítólevél legrégebbi szövegét, azaz a 13. századi hamis oklevelet a 15. század legelejéről fennmaradt többszörös átiratból ismerjük, a Pécsváradi alapítólevél datálása tehát a következő: +1015/+1158 [1220 k.]/1323/1403/PR. (vö. DHA. 1: 63). GYÖRFFY GYÖRGYtöl kezdődően azonban többen is úgy vélekednek, hogy a Pécsváradi oklevél nem teljes egészében hamis oklevél, hanem volt egy 11. századi előzménye, amit a 13. századi hamisításkor kibővítettek. Ennek ellenére több szakmunka is Szent István király korára vonatkozó hamis oklevelek között említi azóta is a Pécsváradi alapítólevelet (lásd például SOLYMOSI 2006: 194-195). A státuszával kapcsolatos bizonytalanságot jól mutatja az is, hogy a DHA.-ban az oklevelet GYÖRFFY GYÖRGY is a falsum, azaz 'hamis' jelzővel illeti, de a latin nyelvü kommentárban emellett azt is megengedi, hogy az 1015-re datált Pécsváradi alapítólevél esetleg nem teljes egészében hamis, hanem maxima parte interpolatum, vagyis nagyrészt utólagos betoldásokat tartalmazó interpolált oklevél (DHA. 1: 63, 72).

Vélhetően azért nem sorolják a diplomatikai munkák a Pécsváradi oklevelet az interpolált oklevelek közé, mert (jelenleg) nem tudjuk olyan módon elkülöníteni az utólagos részeket az eredetiektől, mint ahogyan azt például a Százdi vagy a Garamszentbenedeki oklevél esetében megtehetjük (DHA. 1: 183-185, 213218). Az ugyanakkor bizonyosnak látszik, hogy a hamisításkor forrásként használhatták Szent István oklevelét, illetve más 11. századi oklevelet (DHA. 1: 6970). Az oklevél interpolált voltát GYÖRFFYt megelőzően már HARRY BRESSLAU német diplomatikus is felvetette. A Pannonhalmi oklevéltől eltérő formuláinak a német kancelláriai formulákkal való megfeleltethetősége alapján azt feltételezte,

\footnotetext{
* A tanulmány a Nemzeti Kutatási, Fejlesztési és Innovációs Hivatal (NKFIH) 134389. számú pályázata támogatásával és az MTA-DE Magyar Nyelv- és Névtörténeti Kutatócsoport programja keretében készült.

${ }^{1}$ A hamis oklevél keletkezésének az idejét GYÖRFFY GYÖRGY mellett mások is próbálták időhatárok közé szorítani (vö. SZENTPÉTERY 1918: 36, KISS G. 2001: 89), de nyelvi szempontból elhanyagolható különbségek vannak az egyes elképzelések között.
} 
hogy ugyanaz a német császári scriptor, aki a Pannonhalmi oklevelet lejegyezte, István korában a pécsváradi apátság ügyében is összeállíthatott egy oklevelet (BRESSLAU véleményét idézi SZENTPÉTERY 1918: 19, GYÖRFFY 1969: 202203). A ma ismert hamis oklevél formulás részeinek az eredeti oklevélből való származása mellett az egyházi kiváltságokról szóló részt egyértelmúen, a birtokfelsorolást, illetve az egyházi szerelvények említését pedig valószínűleg hamisnak minősíti (idézi SZENTPÉTERY 1918: 19).

KRISTÓ GYULA ugyancsak egy 11. századi eredeti oklevélre támaszkodó interpolált iratnak tartja a Pécsváradi oklevél szövegét. Véleménye szerint a formulás részeken túl is vannak olyan részei, amelyek az eredetiből származhatnak: a 41 megnevezett birtok, a nagyszámú szolgálónép, a gazdag egyházi felszerelés, illetve az állatok egy jelentős részét Szent István rendelkezése nyomán már az eredeti oklevélben is felsorolhatták. Az eredeti adományok mennyiségéhez a 11. században készült hiteles apátsági oklevelek nyújthatnak esetleg némi támpontot. Feltehető ugyanis, hogy megközelítőleg ugyanannyi adományt kaphatott a Pécsváradi apátság is az alapítójától, mint amennyi például a tihanyi apátság esetében az 1055. évi hiteles és eredeti Tihanyi alapítólevélben szerepel (vö. KRISTÓ 2000: 317). ${ }^{2}$ Mellettük PÜSPÖKI NAGY PÉTER (1989: 40), ÉRSZEGI GÉZA (2000a: 15), KisS GERGELY (2001: 87, 89), illetve THOROCZKAY GÁBOR (2009: 1408) szintén vitathatatlannak látja egy államalapítás kori, hiteles Pécsváradi oklevél létezését.

GYÖRFFY GYÖRGY a hamis 1158. évi oklevél alábbi szövegrészletét használja érvelésében: „ipsa videlicet camara est incensa et sanctissimi Stephani regis a $1 \mathrm{iud}$ privilegi u m a g u m sigilli sui munimine roboratum et apostolica auctoritate confirmatum [...] in eadem camara sunt combusta" (ÉRSZEGI 2000b: 22; a kiemelés tőlem: Sz. M.), azaz „maga a kincstár kigyulladt, és először is Szent István király $\mathrm{n}$ a g y $\mathrm{k}$ i vá $1 \mathrm{t} \mathrm{s}$ á g l e v e $1 \mathrm{e}$, amelyet pecsétje hitelesített és apostoli tekintély erősített meg [...] elégett" (BORONKAINÉ 2000: 24; a kiemelés tőlem: Sz. M.). E szövegrészlet alapján úgy véli, hogy volt egy kisebb, a Pannonhalmi alapítólevél nyomán készült 11. századi Pécsváradi oklevél is, de az bizonytalan, hogy ezt az oklevelet István korában állították-e ki, vagy első királyunk halála után hamisították. Később, a 13. században az interpolátor ezt a 11. századi alapszöveget egészíthette ki több oklevél szövegével, és hozhatta létre a ma István okleveleként ismert hamis oklevelet (GYÖRFFY 1969: 203, DHA. 1: 67-68). A 11. századi kisebb kiváltságlevélen vélhetően azt az oklevelet érti GYÖRFFY GYÖRGY, amelyet 1329-ben Károly király írt át, majd az ő oklevelét 1399-ben Zsigmond király (az oklevél szövegét lásd ÉRSZEGI 2000b:

\footnotetext{
${ }^{2}$ Az oklevél eredeti részeinek kijelölésekor jelentkező bizonytalansági tényezők ellenére az oklevél négy részletéröl szinte teljes bizonyossággal megállapítható 11 . századi voltuk (vö. KRISTÓ 2000: 317-320). Minthogy ezekben a részletekben nincsenek magyar nyelvü elemek, az elemzésük nem mozdítja elő az oklevél nyelvészeti értékelését, ezért ismertetésüktöl el is tekintek.
} 
19-31, magyar fordítását lásd BORONKAINÉ 2000: 32-41). Ebben az oklevélben csak az egyházi kiváltságok szerepelnek, tehát számos olyan adomány hiányzik belőle, amelyek a hamis alapítólevélben megvannak: nem szól például az apátságnak szolgáló népekről vagy az apátság birtokairól. ${ }^{3}$ A hamisítvány legnagyobb részét ugyanakkor a monostor javainak 11. századi összeírásából származtatja (GYÖRFFY 1969: 203, DHA. 1: 70). A már nem létező összeíró oklevél keletkezési idejét Szent László korára datálja, de azt is elképzelhetőnek tartja, hogy egy része István koronázása előtt elkészülhetett. Ez az elképzelés több problémát is felvet: azt például, hogy ki írta volna ezt az oklevelet a német császári kancellária írnokának, Heribert C-nek a Magyarországra érkezése előtt (KRISTÓ 2000: 315).

GYÖRFFY GYÖRGYnek a Pécsváradi összeírás fontos szerepét hangsúlyozó megjegyzésével ugyanakkor kiválóan összecseng KISS GERGELY megállapítása, miszerint az alapitólevél megnevezés helyett kifejezőbb lenne összeíró oklevélnek nevezni a hamis Pécsváradi oklevelet, ez az irat ugyanis alig szól az alapítás körülményeiről, részletesen taglalja viszont az apátság által kapott adományokat (1999: 49, 2001: 88). A hamisítást bizonyítandó a század elején már SZENTPÉTERY IMRE is megjegyezte, hogy a Pécsváradi oklevél birtok- és ingóság-előszámlálása erősen emlékeztet a Bakonybéli összeírás megszövegezésére. Emellett az egyházi szerelvények túlságosan gazdag voltát szintén a Szent László korabeli összeírásokhoz hasonlítja $(1918: 14,16)$. Az összeíró oklevél egykori meglétének, illetve a hamisítványba való bedolgozásának lehetőségét támogathatja HORVÁTH MIHÁLYnak az a feltevése is, miszerint az 1015. évre datált okmány a 11. század vége felé készült kétségtelen hamisítvány (1878: 204-205). A Pécsváradi összeíró oklevél léte melletti érvként szolgálhat mindezek mellett az is, hogy Szent László korában a monostorok mindegyike igyekezett az addig megszerzett javaikat összeíratni, hiszen az írásbeli jogbiztosítékok ekkorra már nélkülözhetetlenné váltak (vö. SzOVÁK 2001: 38). Az összeíró oklevél egykori létezését támogató érvek között tarthatjuk számon végül az oklevélnek azt a jellegzetességét is, hogy a benne elösorolt 41 birtok kivétel nélkül megszámozva szerepel a szövegben: prima Fonsol nominatur; tricesimanona Sholad (DHA. 1: 73, 75), ez a szövegezési mód ugyanis a Szent László korából származó Bakonybéli összeírás föszövegében nem ennyire következetesen, de szintén felfedezhető (DHA. 1: 250-253).

Több érv is szól amellett tehát, hogy a birtokok felsorolása a 11. századi összeírásból származhat, de GYÖRFFY GYÖRGY szerint az apátság alapításkori birtokállományát ismerhetjük meg az oklevélből, azaz a hamis alapítólevélben István adományaként megnevezett birtokokat valósnak fogadhatjuk el. Ez alól csak a

\footnotetext{
${ }^{3}$ A 20. század elején SzENTPÉTERY IMRE fordított irányú hatást feltételezett a két oklevél (a hoszszabb és a rövidebb szövegü Pécsváradi oklevél) között, véleménye szerint ugyanis a hosszabb szövegből rövidítés útján szerkesztették meg az 1329-ben átírt oklevél szövegét (1918: 25-29). SZENTPÉTERY nézetét KisS GERGELY is elfogadja (1999: 57, 2001: 95).
} 
hetedikként megnevezett Baranya megyei Kölked falu kivétel, ez tudniillik csak 1057-ben került az apátság tulajdonába (Gy. 1: 331). A többi birtok István általi adományozása mellett szól az is, hogy a Szent István utáni uralkodók (Domoszló herceg, Szent László és Vak Béla) adományai jól elkülönülve szerepelnek a hamisított szövegben. Az uralkodók adományainak ilyesfajta elhatárolása megengedi azt a következtetést, hogy a Szent István-i adományként megnevezett birtokokat valóban az apátság alapítójától származóknak tekintsük (GYÖRFFY 1977: 235237, DHA. 1: 77-80).

Az oklevél két helynevének (SzÖKE 2019a, 2019b), illetve a mintegy 140 helymegjelölés szövegkörnyezetének (SzŐKE 2020a, 2020b) nyelvi elemzése során több olyan nyelvi körülményre is rámutattam, ami a 11. századbeli rögzítést támogatja. Jelenlegi ismereteink alapján ezek sokkal inkább a század elejéről, mint a végéről származhatnak. Elemzéseim során erre alapozva elfogadom GYÖRFFY álláspontját, hogy tudniillik a hamis alapítólevélben Szent István-i adományként szereplők valóban alapításkori birtokok. Ez pedig azt is jelenti egyúttal, hogy a helyek nevének lejegyzésében akár a század elejéről származó jellegzetességek is feltünhetnek annak ellenére, hogy nem tudjuk pontosan, volt-e egy helyneveket is tartalmazó Szent István-kori oklevél, vagy csupán az összeíró oklevél egy részét jegyezték már le a század elején.

2. A nyelvtörténeti szempontból több idősíkkal rendelkező bizonytalan kronológiai státuszú oklevelek forrásértékének a meghatározásakor fontos szempontként vehető figyelembe a tővégi magánhangzós helynevek jelenléte, illetve hiánya az oklevélben. Ennek a támpontnak az alkalmazása azonban nagy körültekintést igényel. A magyar nyelvtörténeti szakirodalom a véghangzó eltünésének felső határát a 13. század közepében jelöli meg (vö. BÁRCZI 1958: 18-24, valamint E. ABAFFY 2003: 321-323, KATONA CS. 2020: 84-85), ezért például az 1270-es években kibővített interpolált Garamszentbenedeki oklevél időrétegeinek elkülönítésben fontos fogódzóként vehettük figyelembe a véghangzós nevek jelenlétét. Az oklevél véghangzós szórványairól tehát — még akkor is, ha a hangváltozások kronológiai viszonyait messze nem kezelhetjük mereven - viszonylag nagy biztonsággal jelenthettük ki, hogy azok híven megőrizték I. Géza eredeti oklevelének (1075) írásformáját (vö. SzÖKE 2015: 40-41, 60, 96).

A továbbiakban a Pécsváradi oklevél tővégi magánhangzós neveinek ${ }^{4}$ nyelvtörténeti értékelésével kapcsolatos problematikát kívánom körüljárni, különös

\footnotetext{
${ }^{4}$ Vizsgálataimba csak azokat a helymegjelöléseket vontam be, amelyek végén biztosan tővégi magánhangzót találunk, a bizonytalan esetekre — amelyek közül néhányat GYÖRRFY az oklevélbeli sorvadó magánhangzók illusztrálására idéz: például a Kövesd(i) (Kuesty), Kölked(i) (Kulkedy) településnevek vagy a Séd(i) (Sedy) víznév (1977: 236) — nem voltam tekintettel (a névvégi - $i$ funkciójához lásd BÉNYEI 2012: 74-85, KOVÁCS É. 2018: 103-107).
} 
hangsúlyt fektetve arra, hogy milyen valószínüséggel tudjuk ezeket a neveket az oklevél 11. századi kronológiai rétegéhez kötni.

A tővégi magánhangzók meglétének mint fogódzónak az alkalmazása a kronológiai rétegek elkülönítésekor a Pécsváradi oklevél esetében más feltételekkel lehetséges, mint amit a Garamszentbenedeki oklevél kapcsán láthattunk. A Pécsváradi alapítólevél második kronológiai síkjához ugyanis a 13. század első és nem a második feléből származó nyelvi elemek tartoznak. A hamis Pécsváradi oklevélnek a Garamszentbenedeki oklevél interpolált változatához mérten fél évszázaddal korábbi (1220 körüli) keletkezése mellett az is eltérő helyzetet eredményez a két oklevél elemzése között, hogy időközben KATONA CSILLA némiképp módosította a tővégi magánhangzók eltűnésének a végső időpontját. Az ómagyar kori helynevekből összeállított korpusz alapján úgy tünik ugyanis, hogy a tővégi magánhangzók jellemzően csak a 13. század végére tüntek el, azaz meglétükkel — legalábbis bizonyos nyelvjárásokban — még a 13. század második felében is számolni lehet (2020: 94-102). Ez pedig a mi szempontunkból azért fontos, mert ennek értelmében még az 1220 körüli hamisítás alkalmával újonnan a szövegbe került nevek lejegyzésekor is jelölhették a tővégi magánhangzót. Ismét utalnunk kell azonban arra is, hogy helynévtörténeti forrásértéküket tekintve - mint fentebb jeleztem — valamennyi nevet már a 11. században készült oklevélben lejegyezhették, a 13. századi hamisításkor tehát tulajdonképpen a nevek újbóli rögzítése történt meg. Ennek alapján pedig a hamis Pécsváradi alapítólevél tővégi magánhangzós helyneveit is értelemszerúen az oklevél első kronológiai rétegébe sorolhatjuk.

A Pécsváradi alapítólevélben az Árok (ó)út, Nagy-(út-)halom és a Szér nevek lejegyzésében szerepelnek biztosan tővégi magánhangzók: Aruc owtu, Noghutholmu, Zeru. Az Aruc owtu és a Noghutholmu nevek a bizonytalan lokalizációjú Chomur falu leírásában tünnek fel: „Secunda Chomur nominatur, que ab oriente terminatur Balwanus, ab austro Aruc owtu, ab occidente Noghutholmu, a septemtrione Mege" (DHA. 1: 73). A harmadik név pedig a 12. falu neveként szerepel az alapítólevélben: „Duodecima Zeru” (DHA. 1: 74). Ezt a három nevet a hamis oklevél más átirataiban szintén tővéghangzóval találjuk meg: +1015/+1158/1228/ /XVII.: Aruc owtu, +1015/+1158/1228/XV.: Nogu cholmu, illetve esetleg $+1015 /+1158 / 1228 / X V .:$ Zerew, Zereu ${ }^{5}$ A hamis alapítólevél több átiratának a tővéghangzók jelölésében megmutatkozó hasonló eljárásmódja még inkább megerősítheti, hogy a nevek végén a magánhangzók a 11. századi oklevél alapján készült hamis oklevélből származhatnak, azaz visszadatálhatók Szent István korára, és nem például a későbbi átiratokat készítők archaizáló tevékenységének a lenyomatai.

\footnotetext{
${ }^{5}$ A Nogu cholmu, Zereu nevek kikövetkeztetett alakok egy sérült oklevélböl (DHA. 1: 73-74).
} 
A két átirat Szér nevének $(+1015 /+1158$ [1220 k.]/1323/1403/PR.: Zeru, +1015/+1158/1228/XV.: Zerew, Zereu) egymás mellé helyezése azt is nyilvánvalóvá teszi ugyanakkor, hogy bizonyos nevek egészéről nem jelenthető ki, hogy az átírás megőrizte vagy megváltoztatta az átírt oklevél eredeti névalakját, vannak ugyanis részmegoldások is. A [szerü] hangzású településnév esetében a véghangzó jelölése a 11. századtól kezdődően a 13. századi hamisítványban is jelen lehetett, ez ugyanis a forrása az elemzett átiratoknak, az eltérő jelölésmód jól mutatja azonban, hogy az eredeti hangalak megőrzése mellett modernizáló lejegyzéssel is élhettek az oklevélírók: az $\ddot{u}$ hang ew, eu jele nemigen volt ismert a 11. században. Az alapítólevél Zeru nevében a véghangzó jelölése ugyanakkor akár a 11. századból is származhat. Jóllehet az ew és az eu jel sokkal egyszerübben azonosítható hosszú magánhangzók (ö, ü) jeleiként, de a település más oklevélből származó, tehát nem az alapítólevélhez köthető adatai alapján (is) felvethető talán az, hogy tővégi magánhangzó lehet a név végén, és e jelölések nem [szerü] típusú hangalakot jelezhetnek: +1093/1404: Scer, [+1235]/1350/1404: Sceer (Gy. 1: 392). Monográfiájának a tővégi magánhangzókkal foglalkozó fejezetében KATONA CSILla bizonytalanul ugyan, de szintén számba veszi a hamis Pécsváradi oklevél átiratának Zerew nevét (2020: 96).

Hasonló megfigyeléseket tettem a Garamszentbenedeki oklevél Scilu nevének elemzésekor is. A véghangzó megléte alapján az interpolált oklevél első (11. századi) kronológiai rétegéhez soroltam a szórványt, az $s z$ hang $s c$ jele alapján viszont a második (13. századi) réteghez tartozik inkább (SzÖKE 2015: 60). Ugyanez a jelenség került elő a Pécsváradi oklevél Scedluc neve kapcsán is: az eredeti hangalak megörzése mellett a hangok jelölése modernizáltnak tünik. Éppen e név esetében ugyanakkor az is felvetődött, hogy a 11. századra vonatkoztatható okmányok szélesebb körü feltárása után a két kor hangállapotát és -jelölését mutató szórványok csoportját érdemes lehet újra megvizsgálni. Nem zárható ki ugyanis, hogy bizonyos hangjelöléseket korábban azért soroltak a későbbi századokhoz, mert a helyesírás-történeti vizsgálatokba a 11. századból csak meglehetősen csekély számú oklevelet vontak be (vö. SzÖKE 2019a: 114).

Az alapítólevél Noghutholmu szórványának Nagyút-halom névként azonosítását (vö. 'monticulus viae magnae', DHA. 1: 499) némelyest módosíthatja a Szent István-i oklevél egy másik átiratának $(+1015 /+1158 / 1228 / X V$.) Nogu cholmu adata. Egy korábbi munkájában GYÖRFFY GYÖRGY a név Nogu cholmu változatát maga is Nagy-halom-ként és nem Nagyút-halom-ként értelmezi (1977: 236). Az nem szokatlan, hogy az egyjegyü mássalhangzókat $h$-val kiegészítve jegyezték le az oklevelekben (ebben az esetben $g$ helyett $g h$-t írva), a Tihanyi összeírás - ami ugyanabban a korban született, mint a hamis Pécsváradi alapítólevél hitelesített példányában is jó néhányszor találkozunk ezzel a jelenséggel (KOVÁCS É. 2015: 57). A Nagy-halom értelmezés esetén az alapítólevél névformájának elöés utótagja is véghangzóval szerepel: Noghu/tholmu. Ebben az esetben a th 
tévesztés lehet a $c h$ helyett (a $t \sim c$ tévesztés a korabeli betüformák hasonlósága alapján jellemzö), ami igen gyakori volt $\chi$ és $h$ hangértékben egyaránt (KNIEZSA 1952: 17, 21, 27, 187, a halom szó etimológiájához lásd RESZEGI 2011: 83-91).

3. Abból a megállapításból, hogy a 15. századból ránk maradt alapítólevélben tővégi magánhangzóval álló nevek hangalakja a 11. századból származik, természetesen nem következik az, hogy a véghangzó nélküli formák pedig egyértelmủen az oklevél 13. vagy 15. században megváltoztatott részeihez tartoznának. A véghangzóknak az ősmagyar korban meginduló eltünése ugyanis a 11. század első felében is már olyannyira elörehaladott állapotban volt, hogy a helyesírás archaikus, konzervatív volta ellenére a magyar nyelvü elemek jelentős része már tővégi magánhangzó nélkül látható a szórványemlékeinkben (BÁRCZI 1958: 2123). A Tihanyi alapítólevélben például sokkal több alkalommal találunk véghangzó nélküli, mint véghangzós szóalakot (vö. BÁRCZI 1951: 71, HOFFMANN 2010: 140). Ekképpen a 11. századi Pécsváradi oklevélben is előfordulhattak véghangzós és véghangzó nélküli helynevek egyaránt. Az út lexéma például több alkalommal is szerepel az alapítólevélben, s a véghangzós Aruc owtu (DHA. 1: 73) forma mellett a többi véghangzó nélkül van lejegyezve (Nogwt, Owvt, DHA. 1: 73, 74). Ezek között lehetnek esetleg olyanok, amelyeket — a modernizáló lejegyzés lehetőségét szem előtt tartva is — már a 11. században véghangzó nélkül írtak le.

A Pécsváradi alapítólevélben van viszont 11 olyan helymegjelölés, amely tővégi magánhangzó nélkül jelenik meg ugyan a bizonytalan kronológiai státuszú szövegben, mégis elképzelhető, hogy ezek eredetileg véghangzóval kerültek bele a 11. századi hiteles oklevélbe. Az eredeti tővégi magánhangzós alakokra ezúttal a hamis Pécsváradi alapítólevél más átiratainak az írásformája enged következtetni.

Szent István Pécsváradi oklevele több változatban maradt ránk, amelyek közül néhányra már korábban is hivatkoztam. 1158-ban II. Géza átírta első királyunk 1015. évi oklevelét. Ennek az oklevélnek nyoma veszett, de többen is lejegyeztették azt: II. András 1228-ban, IV. László 1274-ben, I. Károly 1323-ban és I. Lajos 1379-ben. GYÖRFFY GYÖRGY alapján tudjuk, hogy az 1158. évi is hamis oklevél, és az 1015. évi oklevéllel együtt csak az 1220-as évek környékén készítették (DHA. 1: 67-70). A felsorolt átiratok tehát tulajdonképpen a 13. század 20-as éveiben készült hamis oklevelet írták át, és többszörös átiratban maradtak fenn. ${ }^{6}$ Alapítólevélként a továbbiakban a pécsváradi apátság számára szóló Szent István-i rendelkezés legrégebbi változatára utalok, amelyet +1015/+1158 [1220 k.]/ 1323/1403/PR. évszámmal szokás jelölni (DHA. 1: 63).

\footnotetext{
${ }^{6}$ A hamisítás idejének meghatározásában is jó iránymutatásul szolgál az első átirat keletkezési időpontja, a hamisítványnak ugyanis még ez elött kellett keletkeznie (vö. SzENTPÉTERY 1918: 36, KIss G. 2001: 93-94).
} 
Az átiratok együttes elemzése iránymutatásul szolgálhat arra vonatkozólag, hogy a 13. századi hamisításkor még véghangzóval írtak le bizonyos neveket. A Pécsváradi alapítólevél átiratainak véghangzói bizonyosan nem származhatnak a 14-18. századi átiratok korából, csakis a közös forrásnak számító 13. századi hamis oklevél nyomán kerülhettek be az alapítólevél ma ismert változataiba. Az oklevélnek ezt a sajátosságát ugyanakkor nem használhatjuk fel a változás záró időpontjának meghatározásához, hiszen a 13. századi hamisítvány egy olyan korban (a 11. században) készült okiratot használt fel forrásként, amikor a véghangzós nevek még nagy arányban voltak jelen nyelvünkben. Azokban az esetekben, amikor akár csak egy vagy több átirat is jelöli ezeket a hangokat, természetesen nem zárható ki egyértelmüen, hogy a 13. században még szerepeltek a nevek végén a véghangzók, de ugyancsak utalhat ez a 11. századi névalakok lejegyzését nem módosító átírásra is. Az egyes nevek kapcsán legbiztosabban tehát csak annyit állapíthatunk meg, hogy a 13. századi hamis oklevélben véghangzóval álltak, de az efféle lejegyzés nem minden esetben jelezte a nevek korabeli (tehát 13. századi) hangzását.

A következő 11 helymegjelölés tünik fel véghangzó nélkül az alapítólevélben, ám a hamis Pécsváradi oklevél más átiratai alapján felvethető, hogy a 11. századi eredeti, illetve a 13. századi hamis oklevélben még véghangzóval álltak (vö. DHA. 1: 72-75): ${ }^{7}$ 1. Nagy-árok a Tolna megyei Zumba határában: Nogarut (+1015/+1158/1228/XV.: Nogu aruc, +1015/+1158/1228//XVII.: Negu Aruk, +1015/+1158/1228//XVIII.: Nagu Aruk); 2. Út a Baranya megyei Bátatő határában: Wt (+1015/+1158/1228/XV.: Vthu); 3. Kökény-kerek a Baranya megyei Kölked határában: Kuchinkereby [o: -kereky] $(+1015 /+1158 / / X V .:$ Kuchinkereku); 4. Három-halom ${ }^{8}$ a Baranya megyei Velente határában: Harumholm $(+1015 /+1158 /$ 1228//XVII.: Karmuholcz); 5. Nagy nyár a Baranya megyei Gorombona határában: Nognar (+1015/+1158/1228/XV.: nognaru); 6. Ravaszlyuk a Baranya megyei Gorombona határában: Rowozluk (+1015/+1158/1228/XV.: Rouzlicu); 7. Ravaszlyuk a Baranya megyei Somló határában: Nouozluk [o: Rovozluk] (+1015/ $+1158 / 1228 / X V .:$ Rouosliku); 8. nagyút a Baranya megyei Kövesdi határában: Nogut (+1015/+1158/1228/XV.: Nogw wtw, +1015/+1158/1228//XVIII.: Nowgwtw); 9. Ó út a Baranya megyei Belisz határában: Owvt (+1015/+1158/1228/XV.: Ou utu); 10. nagyút a Baranya megyei Hird határában: Nogvt $(+1015 /+1158 /$ 1228//XVII.: Negwtu, +1015/+1158/1228//XVIII.: Noguthw); 11. Út a Veszprém

\footnotetext{
${ }^{7}$ E helyütt csak a véghangzóval álló adatokat idézem, közülük is csak azokat, amelyek komolyan számba vehetők a korábbi alakok kikövetkeztetéséhez. A többi formához lásd DHA. 1: 73-75. Az elemzett alapítólevélböl származó adatot évszám nélkül idézem. Ezeknek a datálása minden esetben: +1015/+1158 [1220 k.]/1323/1403/PR.

${ }^{8}$ GYÖRFFY GYÖRGYnél korábban Hamuholm (Gy. 1: 406), ez alapján a KMHsz.-ban Hamu-halom szócikk alatt szerepel a név (1: 121).
} 
megyei Hagymáskér határában: $V t$ ad partem Welpryt $(+1015 /+1158 / 1228 / X V$.: $V t \boldsymbol{w}$ vel $V t h \boldsymbol{u})$.

A fenti feltételezést némiképp elbizonytalaníthatja ugyan az a körülmény, hogy az +1015/+1158/1228/XV. évi átirat, amiböl a legtöbb véghangzós nevet idéztem, sérült állapotában maradt fenn, s ezért sok kikövetkeztetett adat található benne (DHA. 1: 64, 73-75). A Nagy nyár kivételével ugyanakkor a fennmaradó 10 név - akkor is, ha ezt nem idéztem a név romlott volta miatt — más átiratból is adatolható feltehetően véghangzóval: például a Baranya megyei Bátatő határában, illetve a Veszprém megyei Hagymáskér határában lévő Út $(+1015 /+1158 /$ 1228//XVIII.: Vtku, +1015/+1058/1228//XVII.: Otw, DHA. 1: 73, 75).

Az alapítólevél Kuchinkereby [o: -kereky] neve kapcsán elképzelhetö, hogy a földrajzi köznévi utótagként álló kerek lexéma az alapítólevélben sem birtokos személyjeles (Kökény) kereke alakjában (vö. KMHsz. 1: 163), hanem véghangzóval fordul elő, ahogyan más átiratokban is: +1015/+1158/1228/XV.: Kuchinkereku, +1015/+1158/1228/XVIII.: Kuhukeretu (DHA. 1: 73). A kereky lexéma kerekü értelmezése esetén szokatlan lehet a véghangzó jelölöjeként az $y$ az ebben a szerepben általánosan előforduló $u$ jel helyett (KNIEZSA 1952: 191, 195). A Kuchinkereby szórvány kapcsán több ízben is felmerült a tévesztés lehetősége: egyrészt a kereby valószínüleg a kereky helyett áll (Gy. 1: 331), az első névrész, a kökény $i$-ző jellege miatt pedig BÁBA BARBARA számol romlott alakkal e név esetében (2020: 69-70). Talán ebbe a sorba tartozhat a véghangzó y jellel való jelölése is.

4. Összefoglalásul kijelenthetjük, hogy a Pécsváradi alapítólevél nyelvtörténeti kronológiai rétegeinek az elhatárolásakor is sikeresen támaszkodhatunk a véghangzók jelenlétére. Az alapítólevél három véghangzós nevének hangalakját a Szent István-kori oklevélből származtathatjuk. Azokról a nevekről pedig, amelyek az alapítólevélben tővégi magánhangzó nélkül, a 13. századi hamis oklevél más átirataiban viszont véghangzóval szerepelnek, kérdőjelesen ugyan, de felvethető, hogy a 13. századi hamis oklevélben még a nevek 11. századi hangalakját mutató, véghangzós formában voltak jelen. Ebben az esetben véghangzó nélküli modernizáló lejegyzésük a 14. vagy 15. századból származik. Ezek a feltételezések nem a változás lefolyásából adódnak - hiszen ezek alapján már egy véghangzó nélküli név is kiválóan illeszkedhet egy 11. századi szövegbe —, hanem a 13. századi hamis Pécsváradi oklevél különböző átiratainak a névformáiból következnek.

A tanulmányban említett 14 helymegjelölés mellett az alapítólevélben lehetnek még további, a 11. században véghangzóval lejegyezett névformák is, amelyeket vagy már a 13. századi hamisításkor modernizáltak, vagy csak később, a hamis oklevél átírásakor rögzítettek az átírás korához illeszkedő formában. 


\section{Irodalom}

E. ABAFFY ERZSÉBET 2003. Hangtörténet. [Az ómagyar kor.] In: KISS JENŐ-PUSZTAI FERENC szerk. Magyar nyelvtörténet. Budapest, Osiris Kiadó. 301-351.

BÁBA BARBARA 2020. A korai ómagyar kori $i \sim e ́$ szembenállás vizsgálatának lehetőségei és korlátai. Magyar Nyelvjárások 58: 61-79.

BÁRCZI GÉZA 1951. A tihanyi apátság alapitólevele mint nyelvemlék. Budapest, Akadémiai Kiadó.

BÁRCZI GÉZA 1958. Magyar hangtörténet. Második, bővített kiadás. Budapest, Tankönyvkiadó.

BÉNYEI ÁGNES 2012. Helynévképzés a magyarban. A Magyar Névarchívum Kiadványai 26. Debrecen, Debreceni Egyetemi Kiadó.

BORONKAI IVÁNNÉ BELLUS IBOLYA 2000. Szent István pécsváradi alapítólevelének szövege. In: ÉRSZEGI GÉZA, Szent István király pécsváradi alapitólevele. Budapest, Galenus Lapkiadó Kft. 32-43.

DHA. $=$ GYÖRFFY GYÖRGY szerk. 1992. Diplomata Hungariae Antiquissima. Vol. I. Budapest, Akadémiai Kiadó.

ÉRSZEGI GÉZA 2000a. Szent István király pécsváradi alapitólevele. Budapest, Galenus Lapkiadó Kft.

ÉRSZEGI GÉZA 2000b. Szent István pécsváradi alapítólevelének latin szövege. In: ÉRSZEGI GÉZA, Szent István király pécsváradi alapitólevele. Budapest, Galenus Lapkiadó Kft. 19-31.

Gy. = GYÖRFFY GYÖRGY 1963-1998. Az Arpád-kori Magyarország történeti földrajza $I-I V$. Budapest, Akadémiai Kiadó.

GYÖRFFY GYÖRGY 1969. A magyar egyházszervezés kezdeteiről újabb forráskritikai vizsgálatok alapján. MTA Filozófiai és Történettudományok Osztályának Közleményei 18: 199-225.

GYÖRFFY GYÖRGY 1977. István király és müve. Budapest, Gondolat Kiadó.

HOFFMANN IsTVÁn 2010. A Tihanyi alapitólevél mint helynévtörténeti forrás. A Magyar Névarchívum Kiadványai 16. Debrecen, Debreceni Egyetemi Kiadó.

HORVÁTH MiHÁly 1878. A kereszténység első százada Magyarországon. Budapest, Ráth Mór.

KATONA CSILla 2020. Fonotaktikai szerkezetet módositó hangváltozások az ómagyar korban. A Magyar Névarchívum Kiadványai 51. Debrecen, Debreceni Egyetemi Kiadó.

KISS GERGELY 1999. A pécsváradi bencés kolostor birtokainak és egyházjogi kiváltságainak biztosítása a 12-13. században. In: HOMONNAI SAROLTA-PITI FERENCTóTH ILDIKÓ szerk. Tanulmányok a középkori magyar történelemröl. 1. Az 1. Medievisztikai PhD konferencia elöadásai. Szeged, Szegedi Középkorász Mühely. 49-64.

KISS GERGELY 2001. Jogbiztosítás a pécsváradi bencés monostorban a 12-13. században. Adalékok a magyarországi exemptio történetéhez. In: FONT MÁRTA- 
VArgha Dezsö szerk. Tanulmányok Petrovich Ede tiszteletére. Tanulmányok Pécs történetéböl 8. Pécs, Pécs Története Alapítvány. 87-99.

KMHsz. = HOFFMANN IsTVÁN szerk. 2005. Korai magyar helynévszótár 1000-1350. I. Abaúj-Csongrád vármegye. A Magyar Névarchívum Kiadványai 10. Debrecen, Debreceni Egyetem Magyar Nyelvtudományi Tanszéke.

KNIEZSA ISTVÁN 1952. Helyesírásunk története a könyvnyomtatás koráig. Budapest, Akadémiai Kiadó.

KovÁcs Éva 2015. A Tihanyi összeirás mint helynévtörténeti forrás. A Magyar Névarchívum Kiadványai 34. Debrecen, Debreceni Egyetemi Kiadó.

KovÁCs Éva 2018. A névvégi - $i$ lehetséges szerepkörei a 11. században. Helynévtörténeti Tanulmányok 14: 103-113.

KRISTÓ GYULA 2000. Szent István pécsváradi okleveléről. In: PITI FERENC-SZABADOS GYÖRGY szerk. „,Magyaroknak eleiröl”. Ünnepi tanulmányok a hatvan esztendős Makk Ferenc tiszteletére. Szeged, Szegedi Középkorász Mühely. 307-321.

PÜSPÖKI NAGY PÉTER 1989. Az Árpád-kori vásártartás irott emlékei és azok kritikája az államszervezéstöl a tatárjárásig. Piacok és vásárok kezdetei Magyarországon, 1000-1301. Bratislava, Madách.

ResZegi KATALIN 2011. Hegynevek a középkori Magyarországon. A Magyar Névarchívum Kiadványai 21. Debrecen, Debreceni Egyetemi Kiadó.

SOLYMOSI LÁSZLÓ 2006. Írásbeliség és társadalom az Árpád-korban: diplomatikai és pecséttani tanulmányok. Budapest, Argumentum.

SZENTPÉTERY IMRE 1918. Szent István király pécsváradi és pécsi alapitólevele. Budapest, Magyar Tudományos Akadémia.

SzOVÁK KORNÉL 2001. Monachorum pater ac dux. A bencés szerzetesség korai századai Magyarországon. In: TAKÁCs IMRE szerk. Paradisum plantavit. Bencés monostorok a középkori Magyarországon. Pannonhalma, Bencés Főapátság. 35-47.

SzŐKE MELINDA 2015. A garamszentbenedeki apátság alapitólevelének nyelvtörténeti vizsgálata. A Magyar Névarchívum Kiadványai 33. Debrecen, Debreceni Egyetemi Kiadó.

SzŐKE MELINDA 2019a. A Pécsváradi oklevél Scedluc helynevéről. Helynévtörténeti Tanulmányok 15: 107-120.

SzŐKE Melinda 2019b. Szent István Pécsváradi oklevelének Sorlogys helynevéről és ami körülötte lehetett. Névtani Értesitö 41: 91-106.

SzŐKE MELINDA 2020a. A latinizálás és hiánya a pécsváradi apátság alapítólevelében. Névtani Értesitö 42: 29-46.

SzŐKE MELINDA 2020b. A Pécsváradi oklevél helyneveinek szövegkörnyezete. Magyar Nyelvjárások 58: 109-120.

THOROCZKAY GÁBOR 2009. Szent István okleveleiröl. Századok 143: 1385-1412. 


\section{Toponyms with a Stem-Final Vowel in the Founding Charter of Pécsvárad}

When assessing the source value of charters with an uncertain chronological status and having multiple chronological layers from the perspective of historical linguistics, the presence or absence of stem-final vowels may represent a significant factor. In my paper I examine the issues related to the historical linguistic assessment of names in the Charter of Pécsvárad featuring a vowel in the stem-final position, with special attention to the question of how certainly we may associate these names with the $11^{\text {th }}$-century chronological layer of the charter. The charter dated 1015 was forged in the 1220 s and it has survived in a $15^{\text {th }}$-century copy. One of the most important sources for the scribe of the forged charter made at the beginning of the $13^{\text {th }}$ century was the $11^{\text {th }}$-century charter of King Saint Stephen, what is more, the donations under the name of the king recorded in the founding charter known today may be accepted as coming from the $11^{\text {th }}$ century. In line with this, the phonological form of the 3 names including a stem-final vowel in the forged founding charter that has survived in the form of a $15^{\text {th }}$-century copy may certainly be dated from the $11^{\text {th }}$ century: Arok (ó)út 'ditch/(old)road' (Aruc owtu), Nagy-(út-)halom 'large(road)/hillock' (Noghutholmu), Szér settlement name (Zeru).

This does not mean that the forms without the stem-final vowel would definitely belong to the parts of the charter changed in the $13^{\text {th }}$ or $15^{\text {th }}$ centuries. The disappearance of final vowels that started in the proto-Hungarian era was already at an advanced stage in the first half of the $11^{\text {th }}$ century. In the Founding Charter of Pécsvárad, however, there are 11 place designations that appeared in the charter of an uncertain chronological status without a stem-final vowel, based on the spelling of other copies of the founding charter it is still possible that they were originally included in the $11^{\text {th }}$-century authentic charter with a final vowel. The shared source of these copies made in the $14^{\text {th }}-18^{\text {th }}$ centuries was the forged Charter of Pécsvárad from the first half of the $13^{\text {th }}$ century, which relies heavily on the authentic charter of Saint Stephen.

Besides the 14 place designations mentioned in the paper, in the founding charter there may also be name forms recorded in the $11^{\text {th }}$ century with a final vowel, which were modernized either already at the time of the forgery in the $13^{\text {th }}$ century or later when copying the forged charter, adapting the form to the age of copying. 